Prepared for the U.S. Department of Energy under Contract DE-AC05-76RL01830

\title{
Adaptive Management for Decision Making at the Program and Project Levels of the Missouri River Recovery Program
}
RM Thom
D Tyre
MG Anderson
CA Fleming

February 2009 


\title{
DISCLAIMER
}

This report was prepared as an account of work sponsored by an agency of the United States Government. Neither the United States Government nor any agency thereof, nor Battelle Memorial Institute, nor any of their employees, makes any warranty, express or implied, or assumes any legal liability or responsibility for the accuracy, completeness, or usefulness of any information, apparatus, product, or process disclosed, or represents that its use would not infringe privately owned rights. Reference herein to any specific commercial product, process, or service by trade name, trademark, manufacturer, or otherwise does not necessarily constitute or imply its endorsement, recommendation, or favoring by the United States Government or any agency thereof, or Battelle Memorial Institute. The views and opinions of authors expressed herein do not necessarily state or reflect those of the United States Government or any agency thereof.

\author{
PACIFIC NORTHWEST NATIONAL LABORATORY \\ operated by \\ BATTELLE \\ for the \\ UNITED STATES DEPARTMENT OF ENERGY \\ under Contract DE-AC05-76RL01830
}

Printed in the United States of America
Available to DOE and DOE contractors from the Office of Scientific and Technical Information,
P.O. Box 62, Oak Ridge, TN 37831-0062;
ph: (865) 576-8401
fax: $(865) 576-5728$
email: reports@adonis.osti.gov

\footnotetext{
Available to the public from the National Technical Information Service, U.S. Department of Commerce, 5285 Port Royal Rd., Springfield, VA 22161 ph: (800) 553-6847 fax: $(703) 605-6900$ email: orders@ntis.fedworld.gov online ordering: http://www.ntis.gov/ordering.htm
}

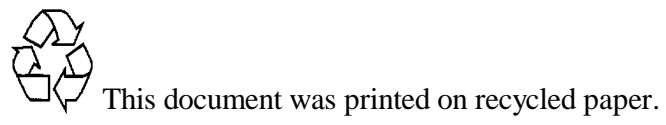




\title{
Adaptive Management for Decision Making at the Program and Project Levels of the Missouri River Recovery Program
}

\author{
RM Thoma \\ MG Anderson ${ }^{\mathrm{a}}$ \\ D Tyreb \\ CA Fleming ${ }^{\mathrm{c}}$ \\ a Pacific Northwest National Laboratory \\ b University of Nebraska-Lincoln \\ c U.S. Army Corps of Engineers, Omaha District
}

February 2009

Prepared for the U.S. Department of Energy under Contract DE-AC05-76RL01830

Pacific Northwest National Laboratory

Richland, Washington 99352 


\section{Ada PTIVE Managemient fOR DeCision Making at THE Program \\ AND ProJect Levels OF THE Missouri RIVER RECOVERY PROGRAM}

Prepared by Ronald Thom (Pacific Northwest National Laboratory [PNNL]), Michael Anderson (PNNL), Andrew Tyre (University of Nebraska-Lincoln), and Craig Fleming (U.S. Army Corps of Engineers, Omaha District)

\section{Introduction}

The paper, "Adaptive Management:

Background for Stakeholders in the Missouri

River Recovery Program," introduced the concept of adaptive management (AM), its principles and how they relate to one-another, how AM is applied, and challenges for its implementation. This companion paper describes how the AM principles were applied to specific management actions within the Missouri River Recovery Program to facilitate understanding, decision-making, and stakeholder engagement. For context, we begin with a brief synopsis of the Missouri River Recovery Program (MRRP) and the

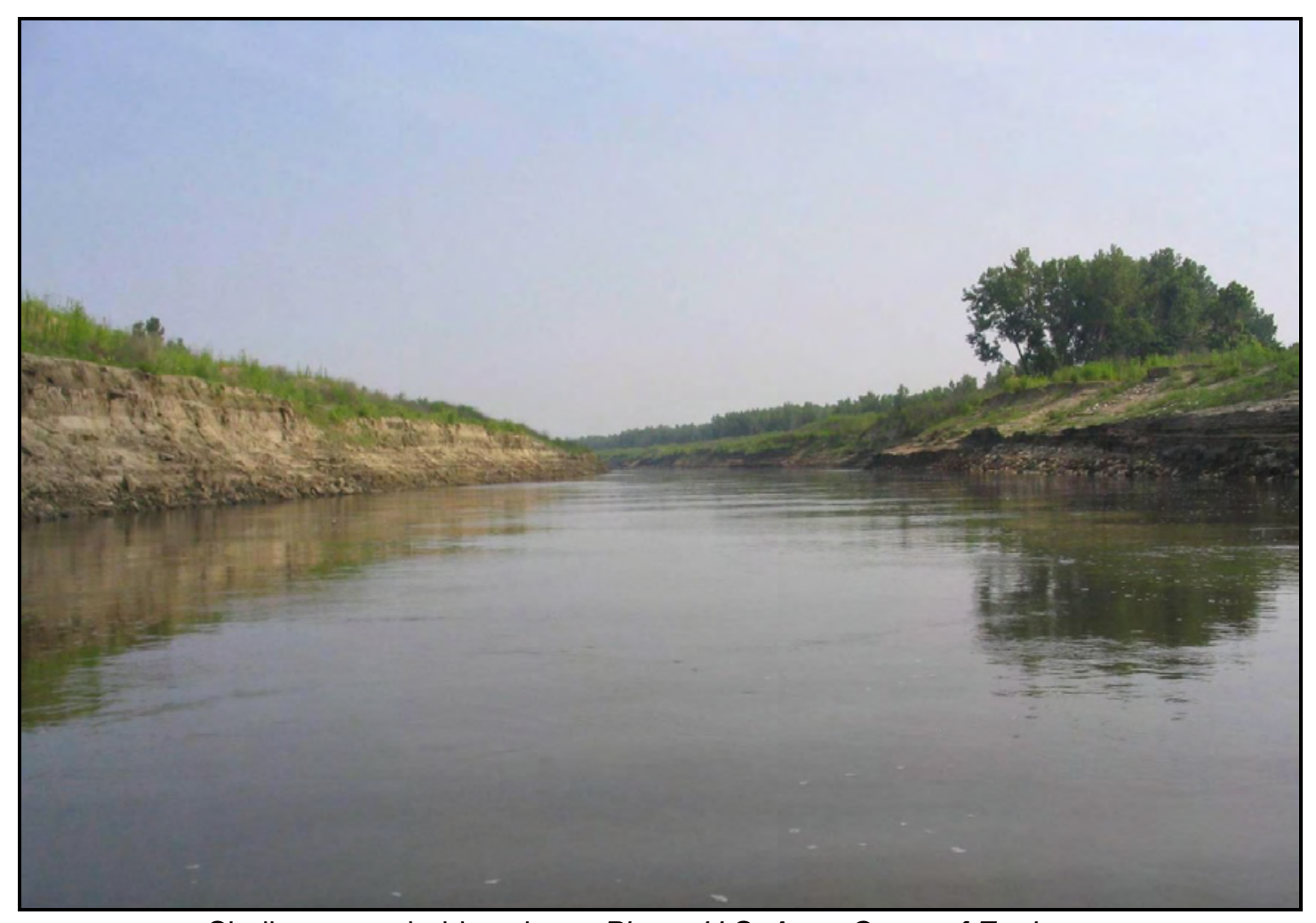

Shallow water habitat chute. Photo: U.S. Army Corps of Engineers strategy for implementing adaptive management within the program; we finish with an example of AM in action within Phase I of the MRPP.

\section{The Missouri River Recovery Program}

The MRRP consists of activities to restore some of the natural form and function of the Missouri River ecosystem to recover the three listed species-Pallid sturgeon (Scaphirhynchus albus), Interior least tern (Sterna antillarum), and Piping plover (Charadrius melodus) -while providing for current social and economic values. This effort will take decades to accomplish and will require more than just the U.S. Army Corps of Engineers (Corps) and the U.S. Fish and Wildlife Service (USFWS) to succeed. The recovery program stands on four foundational pillars: habitat creation, flow modifications, science, and public involvement.

The Corps and USFWS have committed to using AM as the management tool of choice in executing 


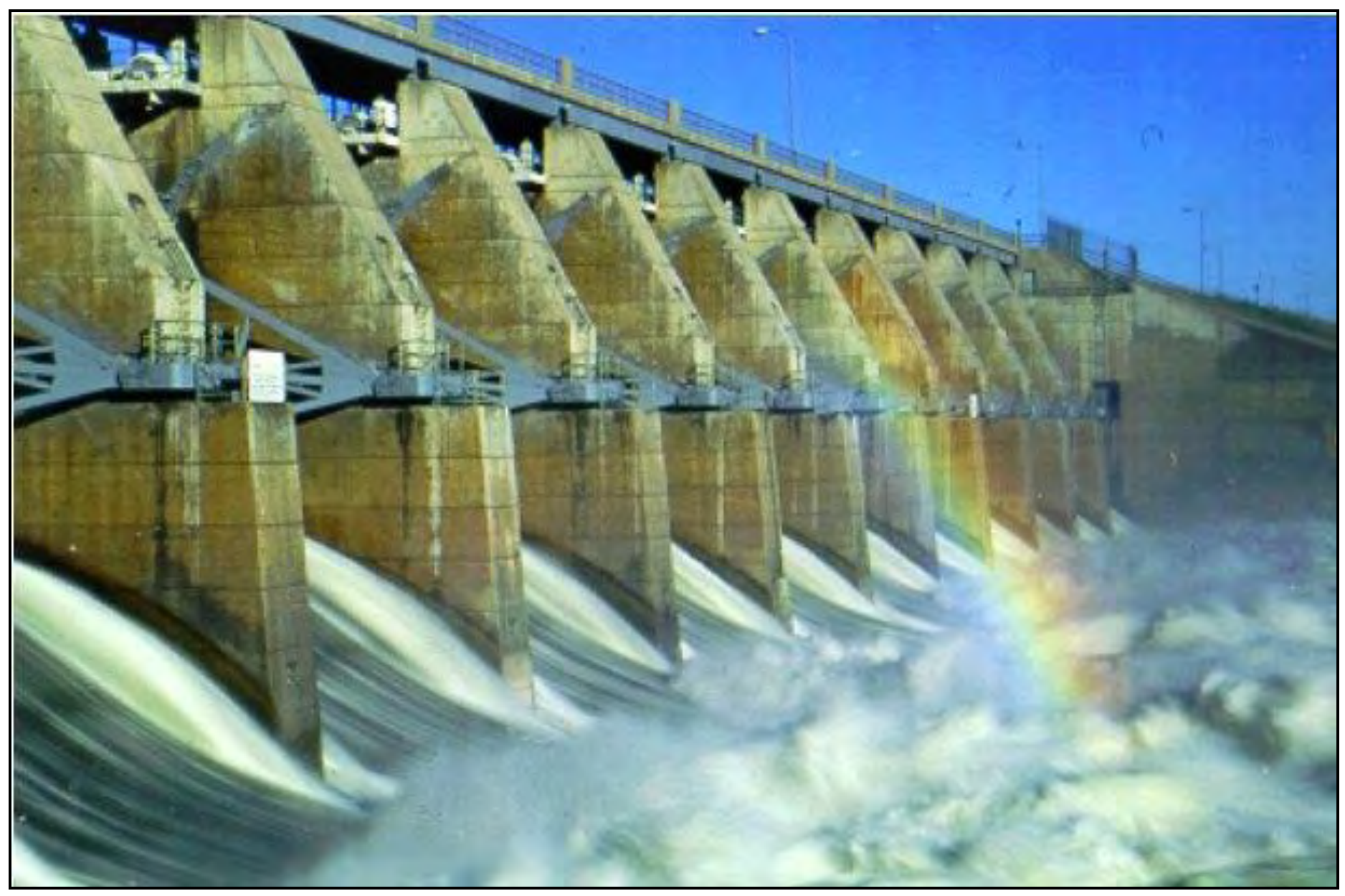

Flow modification. Photo: U.S. Army Corps of Engineers

the MRRP. AM includes stakeholders and others in the process of addressing the uncertainties that exist (scientific, social, and economic) in restoration actions on a large system.

The adaptive management strategy for the MRRP consists of two phases. Phase I is focused on applying AM principles to ongoing management actions (Biological Opinion and Mitigation Program activities) in the near term (5 to 15 years) to improve their ability to meet program goals and objectives. Phase II is a long-term planning process focused on the entire Missouri River system to develop future strategies for the Missouri River through a collaborative planning process developed under the Missouri River Ecosystem Restoration Plan and Environmental Impact
Statement. AM principles will be incorporated into the development and implementation of the plan.

The two program phases are very different in make-up and purpose and require some further explanation:

- Phase I is the starting place for MRRP actions that are already underway within the Corps. Phase I starts with Biological Opinion actions (under the Reasonable and Prudent Alternative or RPA). These are actions described in the Biological Opinion by the USFWS that are likely to help the Corps avoid jeopardy. Jeopardy actions are very different from recovery actions in that avoiding jeopardy means not making things worse than they currently are. So, Phase I starts with RPA actions (which are focused on removing jeopardy) and will 
seek to learn from these actions to move towards recovery by improving them and adding to them as information and collaboration warrants.

- Phase II, on the other hand, will be about recovery. Through the collaborative planning process, assessment of existing information (including information gathered and/or learned during Phase I) will be used to craft alternatives that can truly achieve recovery of the listed species, while also providing for other interests of the system.

We will combat many important subtleties within those statements throughout both phases of this program. For now, it is important to know that the phases are different and why. The remainder of this paper focuses on Phase I AM.

The Biological Opinion ${ }^{1}$ (amended in 2003) contained RPA elements that would help avoid further negative impacts to the listed species. One element, habitat creation (along with habitat restoration), is a principal mechanism for recovering populations of threatened and endangered species. ${ }^{1}$ As one of the four pillars of the MRRP, habitat creation is focused on recovery of species through the creation of the habitats upon which they rely. The RPA includes Shallow Water Habitat (SWH) creation activities for Pallid sturgeon and Interior least

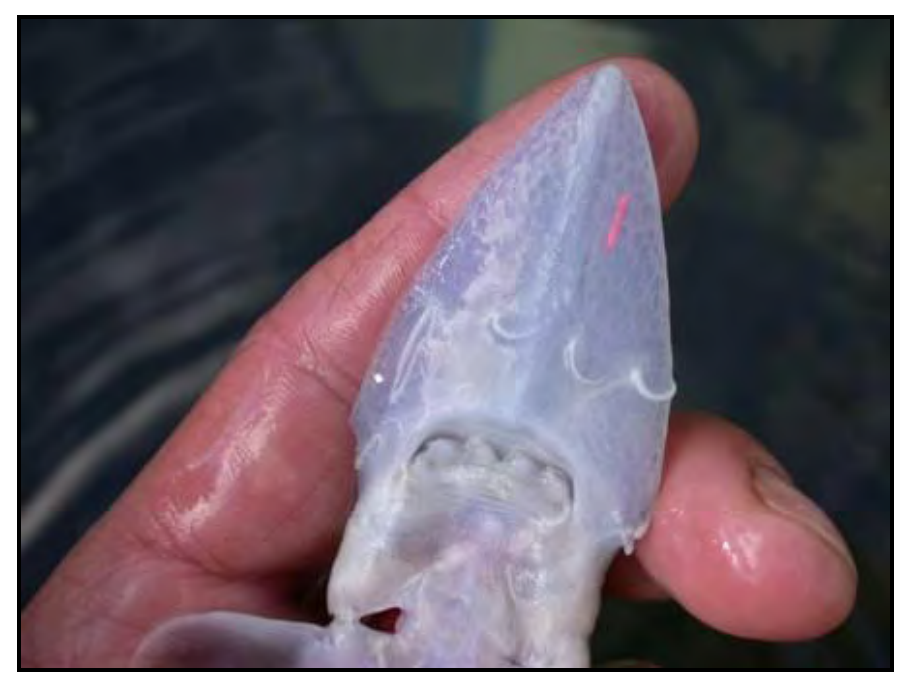

Juvenile Pallid sturgeon. Photo: U.S. Army Corps of Engineers terns (these birds forage for small fishes in SWHs.). The RPA also includes the creation of Emergent Sandbar Habitat (ESH) for Piping plover and Interior least tern forage and nesting habitat.

\section{Phase I Adaptive Management in the Missouri River Recovery Program}

Phase I of the MRRP applies structured decision making to existing activities. The Corps and the Fish and Wildlife Service participated in Rapid Prototyping Workshops with teams of interagency/interdisciplinary people to develop goals, objectives, and models necessary to predict consequences of the management actions being implemented. The models improve our ability to meet program objectives and the individual program goals. So far, we have engaged in Phase I in one area: habitat creation; other RPA elements will be addressed as time and needs dictate. Developing and implementing an adaptive strategy for an action requires working with technical workgroups, the Cooperation for Recovery (CORE) team, stakeholders in the Missouri River Recovery Implementation Committee (MRRIC), and monitoring teams.

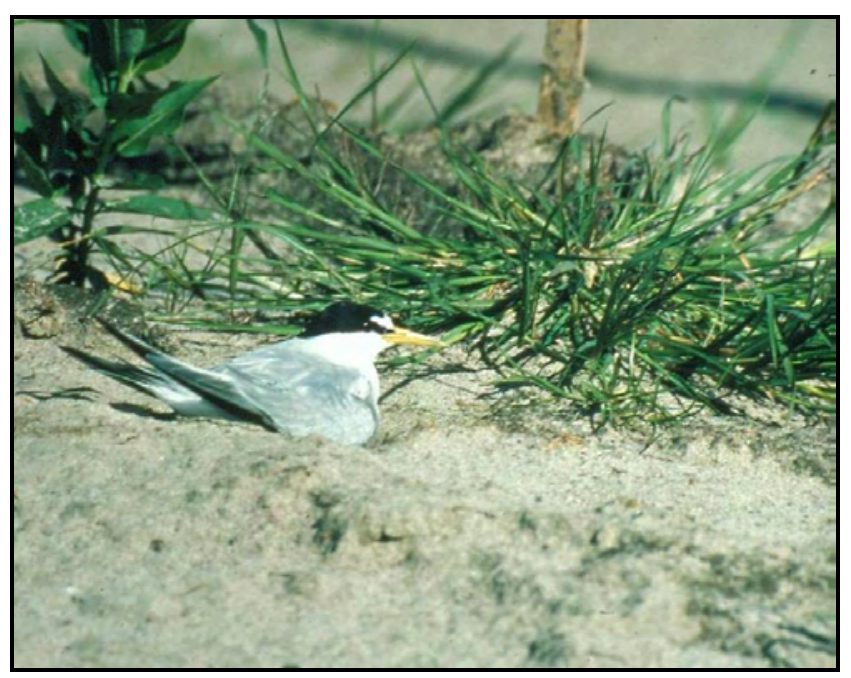

Nesting Interior least tern. Photo: U.S. Army Corps of Engineers 


\section{Pilot Projects with the Missouri River Recovery Program}

Two pilot projects have been initiated under the MRRP.

\section{Shallow Water Habitat Program}

One primary RPA goal is to provide sufficient habitat throughout the lower Missouri River to support self-sustaining populations of Pallid sturgeon by creating 20 to 30 acres per mile of SWH below Gavins Point Dam. ${ }^{1}$ Strategies for creating SWH include widening the main channel (increasing top width), creating side channel chutes, modifying existing habitat, altering summer river flow, or using a combination of the above. SWH is naturally created through two means: 1) erosion of the high banks, and 2) erosion and deposition converting terrestrial acres into aquatic habitat. Widening of channels and construction of chutes requires excavation of bank material and/or modification of the configuration of rock and piling structures of the Bank Stabilization and Navigation Project. After these physical actions, the river is expected to erode the high banks to complete the SWH creation process. Currently, two methods have been used under the MRRP: 1) construction of habitat that is immediately usable by the species, and 2) alteration of existing habitat to promote sedimentation. $^{2}$

\section{Emergent Sandbar Habitat Program}

The Emergent Sandbar Habitat (ESH) Program is a project-level effort designed to improve the outcome of management actions implemented in response to the Biological Opinion on two avian species listed under the Endangered Species Act: the Interior least tern and the Piping plover. Sandbars are being created by building (bulldozing or dredging) new emergent sandbar island habitat, mechanically clearing vegetation from existing sandbars, or by being exposed by adjusting river flow at critical times when habitat is required by the birds.

Construction of the habitat commences during a short period of the year when the birds are absent and when icy conditions do not restrict work. Bird populations typically use ESH between mid-April and August. The USFWS has established sandbar acreage goals to be achieved by 2015 in four sections of the river, including stretches below Garrison Dam, Fort Randall Dam, Gavins Point Dam, and Lewis and Clark Lake. ${ }^{4}$

Both the SWH and ESH programs are being guided by a suite of comprehensive research and monitoring programs conducted by numerous agencies. The science process is guided by engineers and scientists to help understand the complex ecosystem and how system components work together. Numerous uncertainties remain, but the AM plans will ultimately inform the decision-making process as new information is gathered over time and studied collectively among programs.

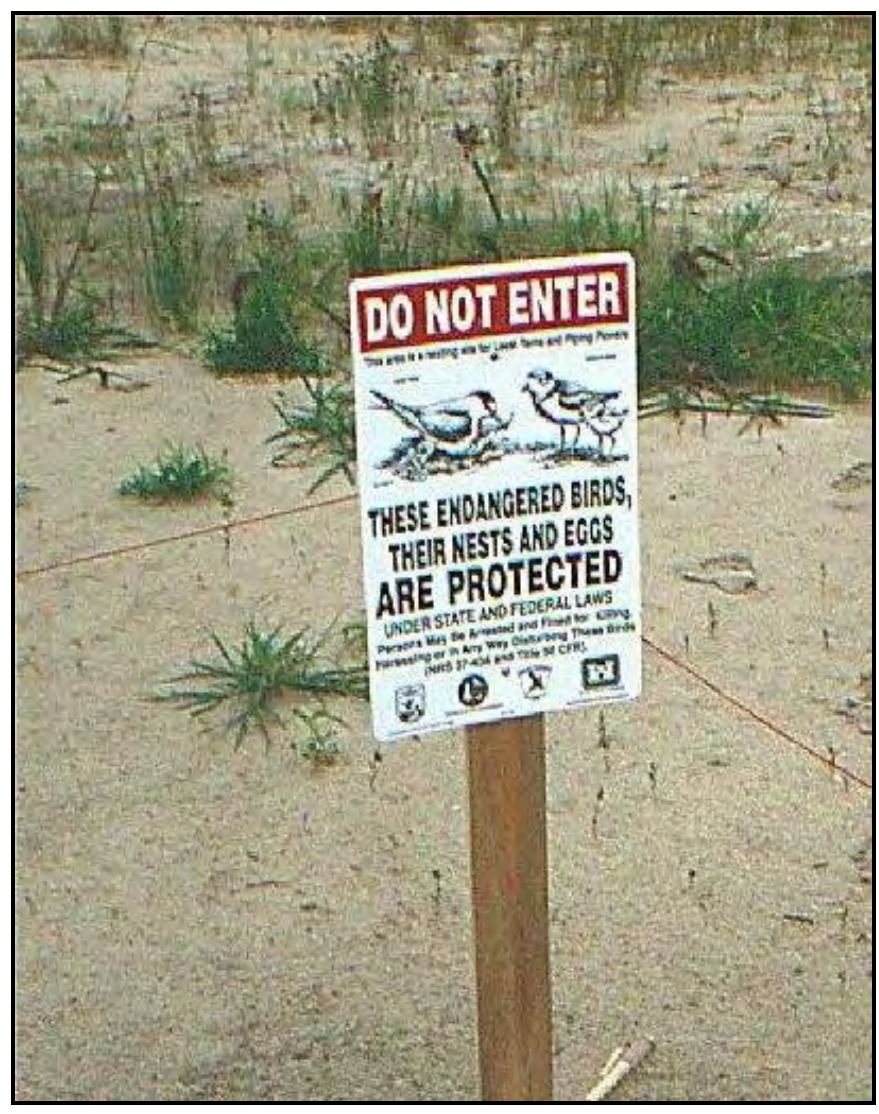

Habitat protection. Photo: U.S. Army Corps of Engineers 


\section{Applying Adaptive Management in the Missouri River Recovery Program}

As was presented in the first paper, an AM process helps attain program goals in an efficient and cost-effective manner. Rather than using trial and error, the MRRP is actively investigating and directing actions based on the analysis of information that is critical to making decisions about what should be implemented. The work to date on this process for SWH is summarized here. Work on ESH has followed a similar path.

History of the Process to Develop an Adaptive Management Strategy for Shallow Water Habitat

To begin developing an AM strategy for SWH, a Structured Decision Making Rapid Prototype workshop was held. The goal of the workshop was to develop a prototype of a SWH decision that would help us see the utility of Structured Decision Making (SDM) for our efforts. Once that value was realize we worked to expand the prototype into an AM plan to guide implementation of the SWH creation actions, monitoring, analyses, and reporting. The SDM approach enables formal evaluation of a complex decision to ensure that all aspects are considered. ${ }^{3}$ Adaptive management is a special case of SDM that arises when the decisions are iterative; that is, the consequences of future decisions depend on the outcomes of past decisions. The set of simple steps addressed at the workshop are as follows:

- Define the problem.

- Describe the objectives.

- List the possible actions.

- Predict the consequences of those actions in terms of the objectives.

- Examine the tradeoffs among the objectives to select the best action.
The SDM steps helped organize the understanding of the interactions and the importance of many of the uncertainties and focus decision-making on key types of information. Some of the products of the SDM workshop were drafts of simple numerical models that can be used to predict the benefit of the SWH creation alternatives to sturgeon. The models and other SDM tools are meant to guide decision-making that maximizes the benefit realized from the MRRP. Uncertainties remain about how well the alternative actions will work to produce the expected result in habitat that provides the maximum benefit to the sturgeon population. The uncertainties are associated with the physical outcomes of actions as well as the biological connections between the actions and the fish.

Program actions taken over the past several years are starting to yield information that is critical to the advancement of the MRRP. As an example, the Habitat Assessment and Monitoring Program (HAMP), and the Pallid Sturgeon Population Assessment Program, as well as other survey and modeling efforts, are supplying data that directly relate to how well various physical actions are working. The HAMP was established to assess the effects of SWH creation on habitat development and fishes occupying the river by studying certain sections of the river before and after actions were taken, as well as sections where no action was taken. Supplemental to the HAMP data, the Pallid Sturgeon Population

Assessment Program will provide the benchmark for determining whether the population is recovering. Taken together, the HAMP and population assessment activities, coupled with monitoring of what actions produced the greatest physical changes in the area of SWH, will inform future decisions about the most efficient and effective means for recovering the species. 


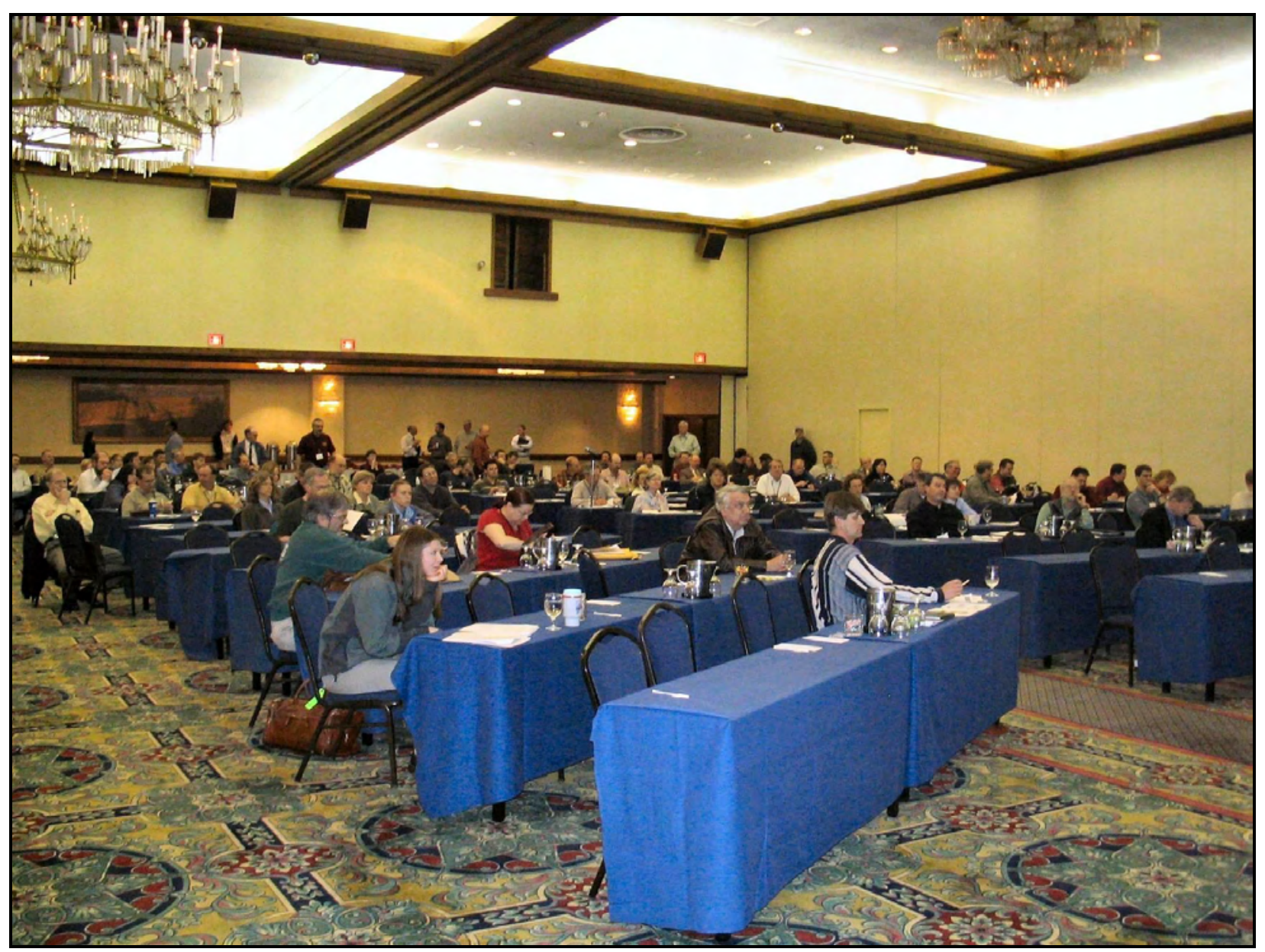

Stakeholder involvement. Photo: U.S. Army Corps of Engineers

\section{Stakeholder Engagement}

As described in the DOI Technical Guide on AM, stakeholders are critical to successful progress in AM. Stakeholders must be involved in the process of reviewing MRRP progress and advising decision-makers. The Missouri River Implementation Committee is looked to as the primary source for stakeholder engagement within the MRRP. The Cooperating for Recovery (CORE) team is responsible for major decisions regarding implementation of the MRRP. Engineers implement creation actions and scientists monitor and report on the relevant results required by the CORE team to make decisions. The addition of stakeholder participation in reviewing the results of the program, asking whether the program is truly meeting its goals, and if not, what is being done to rectify the situation is critical to the success of the MRRP.

\section{Conclusion}

The complexity and incomplete understanding of the Missouri River ecosystem drives the application of the AM principles as described in "Adaptive Management: Background for Stakeholders in the Missouri River Recovery Program," which are helping to shape AM plans for both the SWH and ESH programs. These plans, along with on-the-ground research and monitoring activities, will help ensure that decisions are based on the best available science and those efforts to recover native species move toward the MRRP goal of "A sustainable ecosystem supporting thriving populations of native species while providing for current social and economic values." 


\section{References}

${ }^{1}$ U.S. Fish and Wildlife Service. 2000.

Biological Opinion on the Operation of the Missouri River Main Stem Reservoir System, Operation and Maintenance of the Missouri River Bank Stabilization and Navigation Project, and Operation of the Kansas River Reservoir System. U.S. Fish and Wildlife Service, Fort Snelling, Minnesota.

U.S. Fish and Wildlife Service. 2003. 2003 Amendment to the 2000 Biological Opinion on the Operation of the Missouri River Main Stem Reservoir System, Operation and Maintenance of the Missouri River Bank Stabilization and Navigation Project, and Operation of the Kansas River Reservoir System. U.S. Fish and Wildlife Service, Fort Snelling, Minnesota.
${ }^{2}$ Staroska, A, C Ridenour, C Wrasse, W Doyle, and T Hill. 2008. Pallid Sturgeon Habitat Assessment and Monitoring Program 2007 Annual Report: Segments 10, 13, and 14. United States Fish and Wildlife Service, Columbia National Fish and Wildlife Conservation Office, Columbia, Missouri.

${ }^{3}$ Gregory, RS and RL Keeney. 2002. "Making smarter environmental management decisions." Journal of the American Water Resources Association 38(6):1601-1612.

${ }^{4}$ Missouri River Recovery Program. 2007. Emergent Sandbar Habitat (ESH). Available URL:

http://www.moriverrecovery.org/mrrp/f?p=136:1 32:1941169279106105::NO:::. (Accessed February 5, 2009)

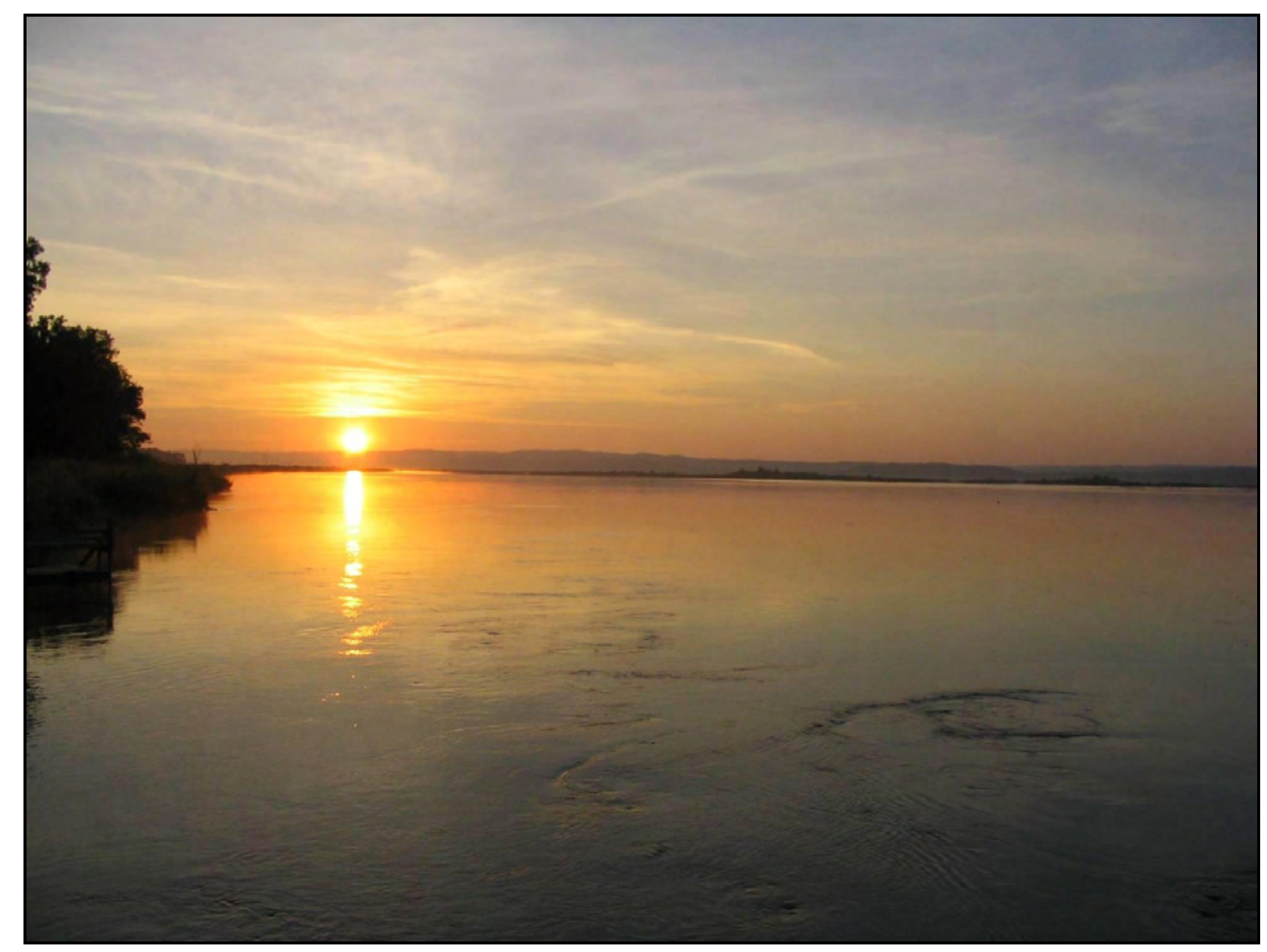

Missouri River sunset. Photo: U.S. Army Corps of Engineers. 


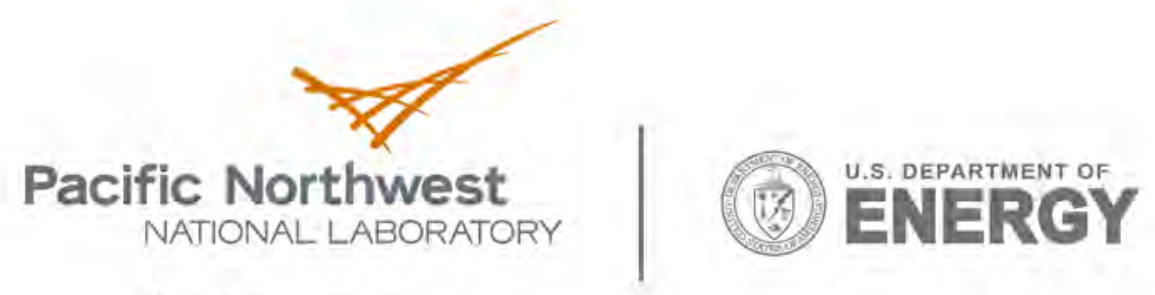

902 Battelle Boulevard

P.O. Box 999

Richland, WA 99352

1-888-375-PNNL (7665)

www.pnl.gov 